\title{
Genetic heterogeneity in leiomyomas of deep soft tissue
}

\author{
Ioannis Panagopoulos ${ }^{1,2}$, Ludmila Gorunova ${ }^{1,2}$, Marta Brunetti ${ }^{1,2}$, Antonio \\ Agostini $^{1,2}$, Hege Kilen Andersen ${ }^{1,2}$, Ingvild Lobmaier ${ }^{3}$, Bodil Bjerkehagen ${ }^{3}$ and \\ Sverre Heim ${ }^{1,2,4}$ \\ 1 Section for Cancer Cytogenetics, Institute for Cancer Genetics and Informatics, The Norwegian Radium Hospital, Oslo \\ University Hospital, Oslo, Norway \\ ${ }^{2}$ Centre for Cancer Biomedicine, Faculty of Medicine, University of Oslo, Oslo, Norway \\ ${ }^{3}$ Department of Pathology, The Norwegian Radium Hospital, Oslo University Hospital, Oslo, Norway \\ ${ }^{4}$ Faculty of Medicine, University of Oslo, Oslo, Norway \\ Correspondence to: loannis Panagopoulos, email: ioannis.panagopoulos@rr-research.no
}

Keywords: leiomyoma of deep soft tissue, cytogenetics, HMGA2, PLAG1

$\begin{array}{lll}\text { Received: February 28, } 2017 \quad \text { Accepted: May 01, } 2017 & \text { Published: May 17, } 2017\end{array}$

Copyright: Panagopoulos et al. This is an open-access article distributed under the terms of the Creative Commons Attribution License 3.0 (CC BY 3.0), which permits unrestricted use, distribution, and reproduction in any medium, provided the original author and source are credited.

\section{ABSTRACT}

Leiomyoma of deep soft tissue is a rare type of benign smooth muscle tumor that mostly occurs in the retroperitoneum or abdominal cavity of women, and about which very little genetic information exists. In the present study, eight leiomyomas of deep soft tissue were genetically analyzed. G-banding showed that three tumors carried rearrangements of the long arm of chromosome 12, three others had $\mathbf{8 q}$ rearrangements, the $7^{\text {th }}$ tumor had deletion of the long arm of chromosome 7, del(7) (q22), and the $8^{\text {th }}$ had aberrations of chromosome bands 3q21 23 and 11q21 22. The target genes of the $12 q$ and $8 q$ aberrations were HMGA2 and PLAG1, respectively. In the leiomyomas with $12 \mathrm{q}$ rearrangements, both HMGA2 and PLAG1 were expressed whereas in the tumors with 8q aberrations, only PLAG1 was expressed. In the cases without 12q or 8q aberrations, the expression of HMGA2 was very low and PLAG1 was expressed only in the case with $\operatorname{del}(7)(q 22)$. All eight leiomyomas of deep soft tissue expressed MED12 but none of them had mutation in exon 2 of that gene. In two tumors with $12 q$ rearrangements, RPSAP52 on $12 q 14.3$ was fused with non-coding RNA (accession number XR_944195) from 14q32.2 or ZFP36L1 from 14q24.1. In a tumor with inv(12), exon 3 of HMGA2 was fused to a sequence in intron 1 of the CRADD gene from 12q22. The present data together with those of our two previous studies in which the fusions KAT6B-KANSL1 and EWSR1-PBX3 were described in two retroperitoneal leiomyomas carrying a $t(10 ; 17)(q 22 ; q 21)$ and a $t(9 ; 22)(q 33 ; q 12)$ translocation, respectively, show that leiomyomas of deep soft tissue are genetically heterogenous but have marked similarities to uterine leiomyomas.

\section{INTRODUCTION}

According to the 2013 edition of "WHO classification of tumours of soft tissue and bone", leiomyoma of deep soft tissue is a "rare type of leiomyoma that occurs in deep soft tissue in the retroperitoneum or abdominal cavity, mostly in women" [1]. Though macroscopically always outside and distinct from the uterus, they have pathological and histological features similar to those of uterine leiomyomas, including common hyaline fibrosis, alternating myxoid change or trabecular patterns, and positivity for estrogen and progesterone receptors [2-4]. The cytogenetics and molecular genetics of retroperitoneal leiomyomas are largely unexplored and in the 2013 edition of "WHO classification of tumours of soft tissue and bone," no genetic information on these tumors can be found [1]. In 2014, mutations in exon 2 of the MED12 gene were reported in $34 \%$ of leiomyomas/ 
leiomyomatoses of pelvic/retroperitoneal sites [5]. The authors concluded that "smooth muscle tumors in pelvic/ retroperitoneal sites are subject to the same mutational changes as those of uterine myometrium, and [that] these mutations may precede the gross or histological development of a leiomyoma" [5].

Recently, we reported the first two cytogenetically analyzed retroperitoneal leiomyomas $[6,7]$. In the first case, the tumor cells carried a $\mathrm{t}(10 ; 17)(\mathrm{q} 22 ; \mathrm{q} 21)$ as the sole karyotypic aberration, the molecular consequence of which was fusion of the KAT6B gene (also known as MORF and MYST4) on 10q22 with the KANSL1 gene (official full name: KAT8 regulatory NSL complex subunit 1) from $17 q 21$ [6]. In the second case, the tumor cells had a $\mathrm{t}(9 ; 22)(\mathrm{q} 33 ; \mathrm{q} 12)$ resulting in a fusion gene consisting of parts of EWSR1 (from 22q12.2) and $P B X 3$ (from 9q33.3) [7]. These two studies showed that retroperitoneal leiomyomas may be characterized by fusion genes coding for chimeric proteins. However, the finding of different fusions indicated genetic heterogeneity and that various pathways could lead to retroperitoneal leiomyomagenesis.

We present here the genetic analysis of eight leiomyomas of deep soft tissue providing support for the conclusion that genetic heterogeneity, similar to the heterogeneity seen in their uterine counterparts, is a feature of these tumors.

\section{RESULTS}

\section{Patients}

All patients were females from 43 to 73 years old with a median age of 54 . There was no history of uterine leiomyoma/hysterectomy (no information was available for case 5, Table 1). The tumor was single mass in all patients. The tumors were positive for estrogen receptor and progesterone receptor (no information was available for case 6). Table 1 shows the patients' gender, age, diagnosis, location and largest diameter of the tumors, and the results of immunohistochemical examinations using actin, aortic smooth muscle actin (SMA), desmin, L-caldesmon, estrogen receptor, and progesterone receptor. Figure 1 shows an H\&E-stained section from case 4 as well as the immunoexpression of actin, SMA, desmin, and L-caldesmon in the same tumor.

\section{Cytogenetics}

Based on the results of G-banding analysis, the leiomyomas were divided in 4 groups (Table 1, Figure 2): The first group consisted of leiomyomas with $12 q$ rearrangements (cases 1-3). Case 1 had complex changes that included $\operatorname{del}(12)(\mathrm{q} 13 \mathrm{q} 21)$ and ins(12;?)
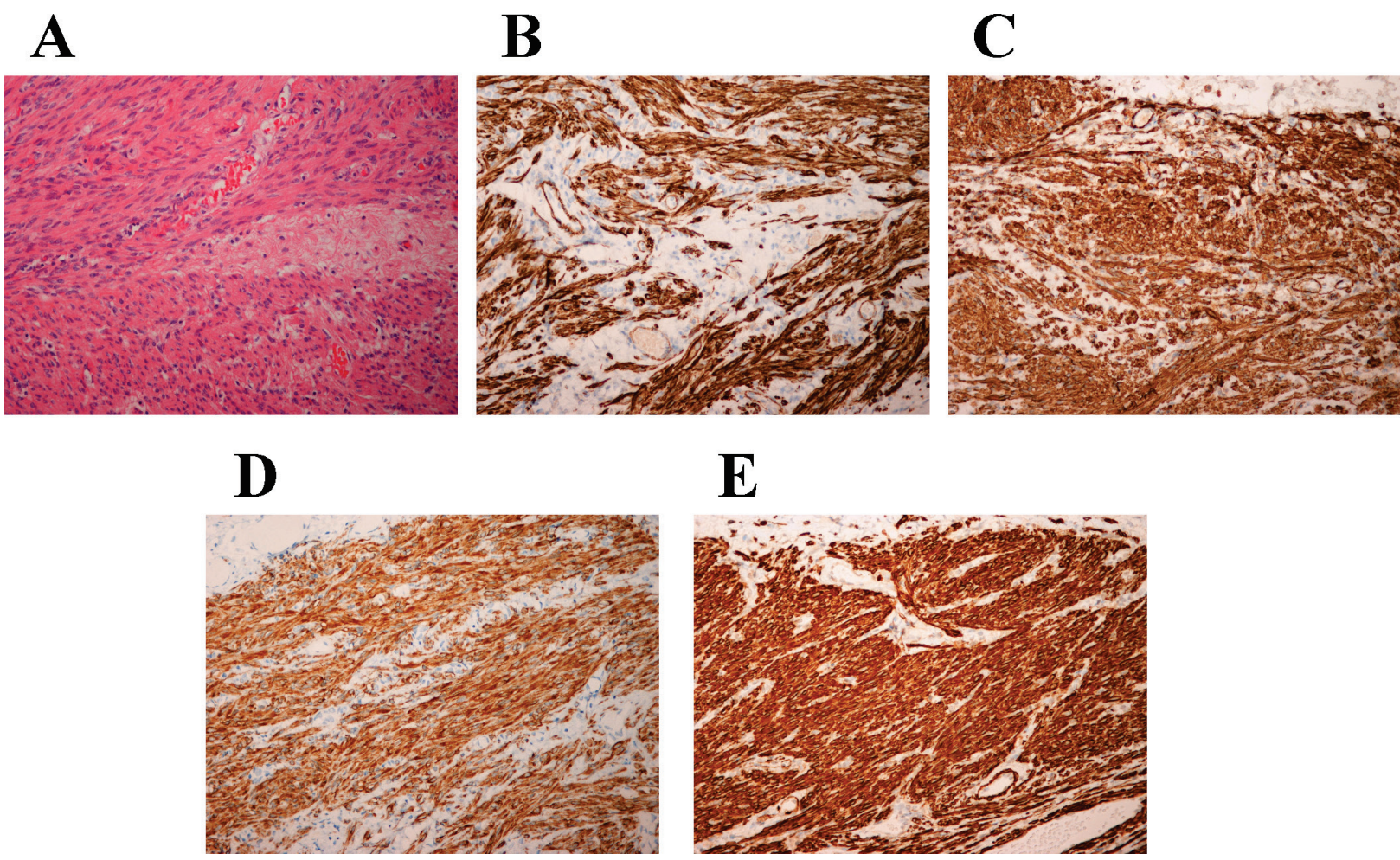

Figure 1: Histological examination of the leiomyoma of deep soft tissue of case 4. A. H\&E-stained slide. B. Immunoexpression of actin. C. Immunoexpression of SMA. D. Immunoexpression of desmin. E. Immunoexpression of L-caldesmon. Magnification for all slides is $\mathrm{x} 20$. 
Table 1: Clinicopathological data, karyotypes, interphase FISH results, and expressions of the HMGA2 and PLAG1 genes in eight leiomyomas of deep soft tissue.

\begin{tabular}{|c|c|c|c|c|c|c|c|c|c|}
\hline Case & $\begin{array}{l}\text { Sex/ } \\
\text { Age }\end{array}$ & Location & $\begin{array}{l}\text { Largest } \\
\text { diameter } \\
(\mathrm{cm})\end{array}$ & $\begin{array}{l}\text { Immunohistochemistry- } \\
\text { positive staining }\end{array}$ & Group & Karyotype & $\begin{array}{l}\text { Interphase } \\
\text { FISH } \\
\text { rearrange- } \\
\text { ments } \\
\end{array}$ & $\begin{array}{l}\text { Expression } \\
\text { of } H M G A 2^{\mathrm{a}}\end{array}$ & $\begin{array}{l}\text { Expression } \\
\text { of } P L A G 1^{a}\end{array}$ \\
\hline 1 & $\mathrm{~F} / 53$ & retroperitoneum & 11 & \begin{tabular}{|lr}
$\begin{array}{l}\text { Actin, SMA, desmin, estrogen } \\
\text { receptor, } \\
\text { receptor }\end{array}$ & progesterone \\
\end{tabular} & 1 & $\begin{array}{l}\text { 44 45,XX,der(12)del(12) } \\
\text { (q13q21)ins(12;?)(q13;?),del(14) } \\
\text { (q22),-21,-22[cp11] }\end{array}$ & $\begin{array}{l}H M G A 2 \\
(73 \%)\end{array}$ & $5.31 \pm 0.19$ & $0.62 \pm 0.06$ \\
\hline 2 & $\mathrm{~F} / 47$ & $\begin{array}{l}\text { preperitoneal } \\
\text { adipose tissue }\end{array}$ & 7 & $\begin{array}{l}\text { Actin, desmin, } \\
\text { estrogen receptor, } \\
\text { progesterone receptor }\end{array}$ & 1 & $\begin{array}{l}\text { 45 46,XX,inv(12)(p11q15) } \\
{[\mathrm{cp} 12] / 46, X X[2]}\end{array}$ & $\begin{array}{l}H M G A 2 \\
(43 \%)\end{array}$ & $0.78 \pm 0.06$ & $0.12 \pm 0.01$ \\
\hline 3 & F/68 & preperitoneal & 6 & $\begin{array}{l}\text { Actin, SMA, desmin, } \\
\text { L-caldesmon, } \\
\text { estrogen receptor, } \\
\text { progesterone receptor }\end{array}$ & 1 & $\begin{array}{l}\text { 46,XX,t(3;13)(p21;p13),del(5) } \\
\text { (q331q33),t(12;14)(q15;q24) } \\
{[5] / 46, i \operatorname{dem}, \operatorname{del}(9)(\mathrm{q} 22)[10]}\end{array}$ & $\begin{array}{l}\text { HMGA2 } \\
(98 \%)\end{array}$ & $0.48 \pm 0.09$ & $0.42 \pm 0.02$ \\
\hline 4 & $\mathrm{~F} / 53$ & ovary/peritoneum & 7 & $\begin{array}{l}\text { Actin, SMA, desmin, } \\
\text { L-caldesmon, } \\
\text { estrogen receptor, } \\
\text { progesterone receptor }\end{array}$ & 2 & $46, X X$, ins $(8)(p 23 q 12 q 22)[30]$ & $\begin{array}{l}\text { PLAG1 } \\
(75 \%)\end{array}$ & 0.00 & $5.85 \pm 0.60$ \\
\hline 5 & $\mathrm{~F} / 43$ & $\begin{array}{l}\text { abdominal wall/ } \\
\text { groin muscles }\end{array}$ & 9 & $\begin{array}{l}\text { SMA, desmin, } \\
\text { estrogen receptor, } \\
\text { progesterone receptor }\end{array}$ & 2 & $46, \mathrm{XX}, \mathrm{t}(8 ; 14)(\mathrm{q} 13 ; \mathrm{q} 24)[15]$ & $\begin{array}{l}\text { PLAGI } \\
(86 \%)\end{array}$ & Not done & Not done \\
\hline 6 & F/69 & abdomen & 11.5 & Actin, SMA, desmin & 2 & $\begin{array}{l}\text { 46,XX,t(8;19)(q12;q13) } \\
{[12] / 46, \mathrm{XX}[3]}\end{array}$ & Not done & 0.00 & $0.42 \pm 0.08$ \\
\hline 7 & $\mathrm{~F} / 73$ & $\begin{array}{l}\text { retroperitoneal/ } \\
\text { left kidney }\end{array}$ & 9.5 & $\begin{array}{l}\text { SMA, desmin, estrogen } \\
\text { receptor, } \\
\text { receptor }\end{array}$ & 3 & $\begin{array}{l}\text { 45 46,XX,del(7)(q22) } \\
\text { [cp6]/45 46,idem,?del(14)(q24) } \\
\text { [cp6] }\end{array}$ & Not done & $0.02 \pm 0.00$ & $0.39 \pm 0.02$ \\
\hline 8 & $\mathrm{~F} / 56$ & abdominal wall & 6.5 & $\begin{array}{l}\text { Estrogen receptor, } \\
\text { progesterone receptor }\end{array}$ & 4 & $\begin{array}{l}46, \mathrm{XX}, ? \mathrm{der}(3) \mathrm{t}(3 ; 11) \\
\text { (q21 q23; q21 q22), add(11) } \\
\text { (q21)[12] }\end{array}$ & Not done & $0.04 \pm 0.00$ & 0.00 \\
\hline
\end{tabular}

${ }^{a}$ Expressions of $H M G A 2$ and PLAG1 were based on real-time PCR and the $2^{-\triangle \triangle C q}$ (Livak) method. The numbers are relative normalized expression \pm standard error of the mean. The relative expression was calculated and set as 1 for human reference.

(q13;?) together with del(14)(q22) and monosomies for chromosomes 21 and 22. Case 2 had inv(12)(p11q15) as the sole abnormality. Case 3 had a $t(12 ; 14)(15 ; q 24)$ translocation together with $\mathrm{t}(3 ; 13)(\mathrm{p} 21 ; \mathrm{p} 13)$ and $\operatorname{del}(5)$ (q31q33). The second group consisted of leiomyomas carrying $8 \mathrm{q}$ rearrangements (cases 4-6). The tumors in cases 4,5 , and 6 had ins(8)(p23q12q22), t(8;14)(q13;q24), and $\mathrm{t}(8 ; 19)(\mathrm{q} 12 ; \mathrm{q} 13)$ as sole cytogenetic abnormalities, respectively. The third group consisted of a single tumor with $\operatorname{del}(7)(q 22)$ (case 7). In a subclone, $\operatorname{del}(14)(q 24)$ was present in addition to deletion of $7 \mathrm{q}$. The fourth group consisted of a tumor (case 8) with other cytogenetic aberrations: $\operatorname{der}(3) \mathrm{t}(3 ; 11)(\mathrm{q} 21 \sim 23 ; \mathrm{q} 21 \sim 22)$ and $\operatorname{add}(11)$ $(\mathrm{q} 21)$.

\section{Fluorescence in situ hybridization (FISH) analysis}

FISH with an HMGA2 breakapart probe on interphase nuclei from cases $1-3$ carrying $12 \mathrm{q}$ aberrations showed rearrangements of the HMGA2 locus in $73 \%, 43$ $\%$, and $98 \%$ of the examined nuclei, respectively (Table 1, Figure 3). FISH on metaphase spreads was also possible (Figure 3 ). In case 1, the analysis showed deletion of the $5^{\prime}$-end of the probe (red signal). In case 2 , the 3 '-end of the probe (green signal) had moved to $12 \mathrm{p}$. In case 3 , the analysis showed that the 3 '-end of the probe (green signal) had moved to $14 \mathrm{q}$.

FISH with a PLAG1 breakapart probe on interphase nuclei from the tumors of cases 4 and 5 , which carried an
$8 \mathrm{q}$ aberrations, showed rearrangement of PLAG1 in $75 \%$ and $86 \%$ of the examined nuclei, respectively (Table 1 , Figure 4). FISH on metaphase spreads from case 5 showed that the 3 '-end of the probe (green signal) had moved to der(14) whereas the $5^{\prime}$-end of the probe remained on $\operatorname{der}(8)$ (Figure 4).

FISH could not be performed on cells from cases 6,7 , and 8 .

\section{Expression of $H M G A 2$ and $P L A G 1$}

Results of the expression analysis for genes HMGA2 and PLAG1 using real-time PCR and the $2^{-\Delta \Delta \mathrm{Cq}}$ method are shown in Table 1 . In cases 1 and 2, with $12 \mathrm{q}$ rearrangements, $H M G A 2$ expression was approximately 8 and 6 times, respectively, stronger than the expression of PLAG1. No difference between HMGA2 and PLAG1 expression was seen in case 3 which also had a $12 \mathrm{q}$ abnormality. In cases 4 and 6 , with $8 \mathrm{q}$ rearrangements, PLAG1 but not HMGA2 was expressed. In case 7, with $\operatorname{del}(7)(\mathrm{q} 22)$, and in case 8 , with other changes, the expression of $H M G A 2$ was very low. PLAG1 was expressed in case 7 but not in case 8 (Table 1).

\section{Expression of $M E D 12$ and mutations in exon 2 of MED12}

RT-PCR with the primers MED12-Ex1-F/MED12Ex3-R amplified a 163 bp cDNA fragment in all examined 
leiomyomas of deep soft tissue (Figure 5). It contained part of exon 1, the entire exon 2, and part of exon 3 of the $M E D 12$ gene suggesting that MED12 was expressed. Sequencing of the PCR product did not show any mutation in the amplified cDNA fragment of MED12 (data not

\section{GROUP 1: 12q ANOMALIES}
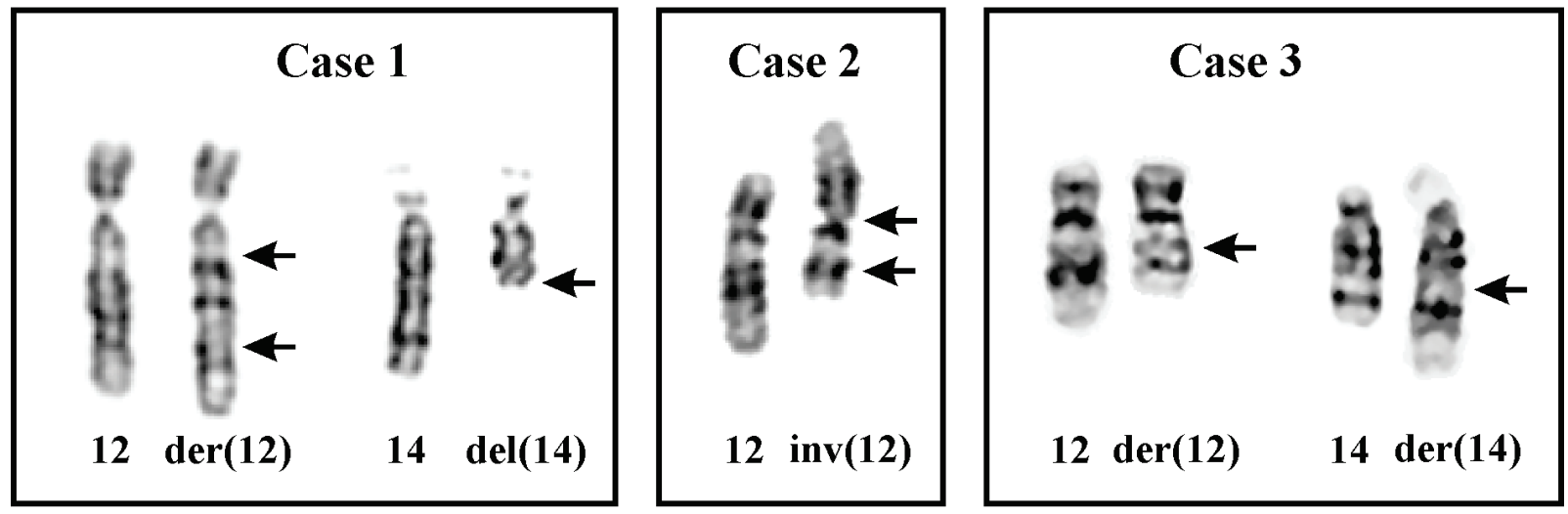

\section{GROUP 2: 8q ANOMALIES}
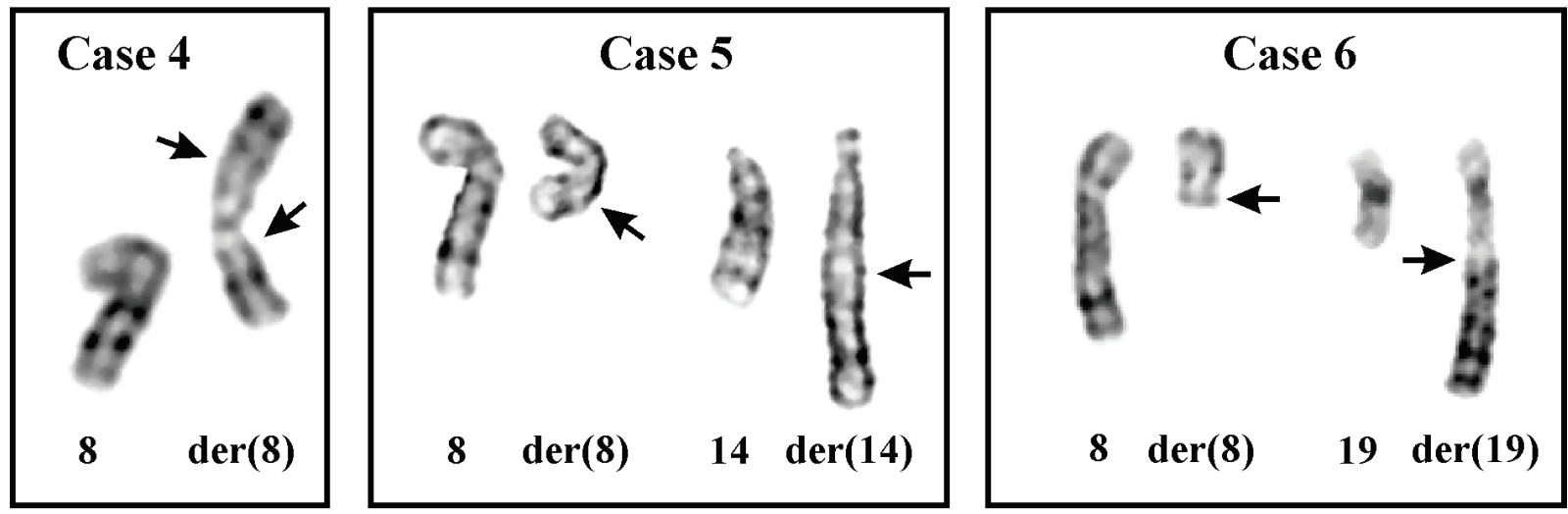

\section{GROUP 3: 7q ANOMALIES}

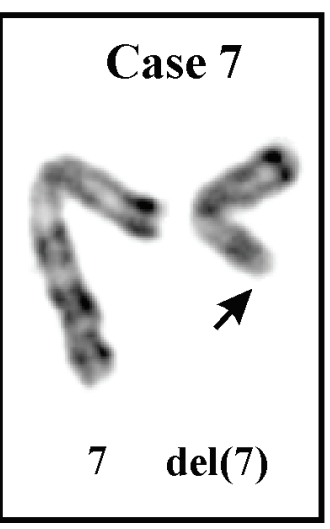

Figure 2: Cytogenetic analysis of leiomyomas of deep soft tissue. Partial karyotypes of tumors of group 1 with $12 \mathrm{q}$ anomalies (cases 1-3), group 2 with 8q anomalies (cases 4-6), and group 3 with deletion 7q (case 7). The description of aberrations is given in Table 1. Arrows indicate breakpoints. 
RNA-sequencing and verification of fusions

RNA-sequencing was performed for cases 1 and 3 in order to find fusion genes related to $12 \mathrm{q} /$ $H M G A 2$. In case 1, a fusion of the ribosomal protein SA pseudogene 52 (RPSAP52) with the sequence with accession number XR_944195 was found (Figure 6). The RPSAP52 pseudogene (accession number NR_026825.2, https://www.ncbi.nlm.nih.gov/nuccore/ NR 026825? report $=$ GenBank) maps on $12 \mathrm{q} 14.3$, next to $H M G A 2$, and has two exons (https://www.ncbi.nlm. nih.gov/gene/204010). Exon 1 of RPSAP52 is within intron 1 of $H M G A 2$. The sequence with accession number XR_944195 (https://www.ncbi.nlm.nih.gov/nuccore/ XR_944195) is a long non-coding RNA which maps on chromosome subband 14q32.2. RT-PCR followed by Sanger sequencing verified the presence of the RPSAP52$X R \_044195$ fusion transcript in the tumor.

In case 3 , the analysis detected a fusion between a sequence from RPSAP52 and the ZFP36L1 gene (ZFP36 ring finger protein like 1) which maps on chromosome subband 14q24.1 (Figure 6). RT-PCR followed by

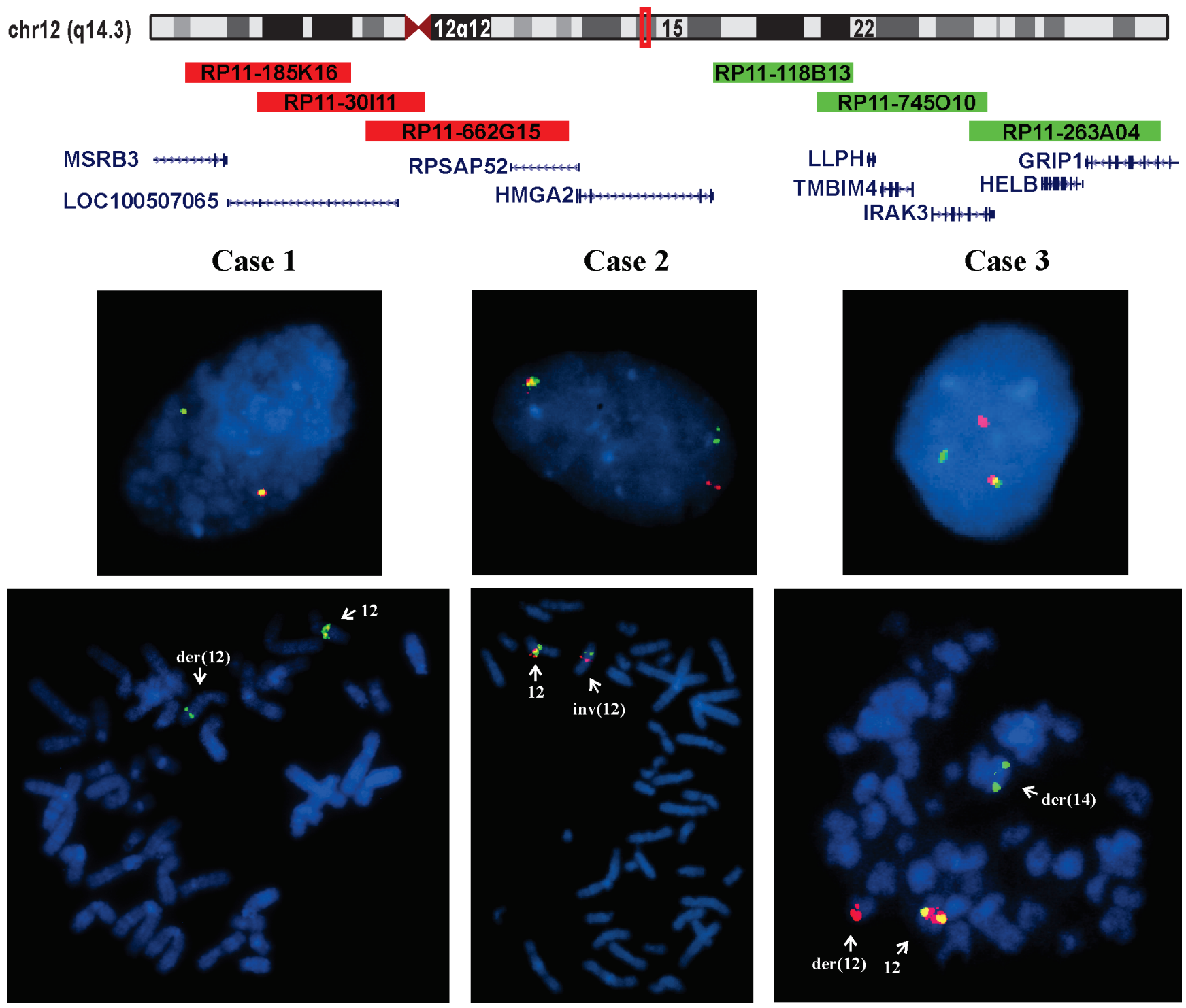

Figure 3: Interphase and metaphase FISH analyses of leiomyomas of deep soft tissue from group 1 with $12 q$ anomalies. Ideogram of chromosome 12 with the location of HMGA2 (red box) and the BACs used for FISH experiments are shown. The $5^{\prime}$-end of the probe (red signal) was constructed from a pool of the clones RP11-185K16, RP11-30I11, and RP11-662G15. The 3'-end of the probe (green signal) was constructed from a pool of the clones RP118B13, RP11-745O10, and RP11-263A04. In case 1, the analysis showed absence of the red signal (deletion of the $5^{\prime}$-end of the probe) in both metaphase spreads and interphase nuclei. In case 2, interphase FISH showed split between red and green signals ( $5^{\prime}$-end and 3'-end probes). The FISH on metaphase spreads showed that the green signal (3'-end of the probe) was moved to $12 \mathrm{p}$. In case 3, interphase FISH showed split between red and green signals ( $5^{\prime}$-end and $3{ }^{\prime}$-end probes). The FISH on metaphase spreads showed that the green signal ( 3 '-end of the probe) had moved to $14 \mathrm{q}$. 
Sanger sequencing verified the presence of the ZFP36L1RPSAP52 fusion transcript.

In case 2, 3'-RACE amplified a single fragment (Figure 6). Sanger sequencing showed that it was a chimeric cDNA in which exon 3 of $H M G A 2$ was fused to a sequence in intron 1 of the $C R A D D$ gene from $12 \mathrm{q} 22$ (Figure 6). PCR with $H M G A 2$ forward and $C R A D D$ reverse primers amplified a cDNA fragment which by direct sequencing was shown to contain the same fusion point as the 3 '-RACE amplified fragment (Figure 6).

\section{DISCUSSION}

The presented data show that leiomyomas of deep soft tissue are genetically heterogenous and may arise through various tumorigenic pathways, most of which are already known from studies of uterine leiomyomas. Three out of the eight tumors had $12 \mathrm{q}$ aberrations (cases 1-3; Table 1). The translocation $\mathrm{t}(12 ; 14)(\mathrm{q} 15 ; \mathrm{q} 24)$ found in case 3 is similar to that found in $20 \%$ of karyotypically abnormal uterine leiomyomas [8, 9]. Complex karyotypes with $12 \mathrm{q} 14 \sim 15$ and $14 \mathrm{q} 22$ rearrangements (case 3) were also reported in uterine leiomyomas [9]. In case 2 , a pericentric inversion, $\operatorname{inv}(12)(\mathrm{p} 11 \mathrm{q} 15)$, was found as the sole chromosomal abnormality. Again, similar inversions of chromosome 12 were also seen in uterine leiomyomas [9]. In addition, a leiomyoma of the vulva was reported to have an $\operatorname{inv}(12)(\mathrm{p} 12 \mathrm{q} 13 \sim 14)$ as the sole karyotypic change [10]. In FISH experiments, deletion of the $5^{\prime}$-end of the HMGA2 probe (case 1) and moving of the $3^{\prime}$-end of the probe to $12 \mathrm{p}$ (case 2 ) or $14 \mathrm{q}$ (case 3 ) indicated that the rearrangements of $12 \mathrm{q} 14 \sim 15$ targeted the HMGA2 locus. The molecular analyses verified the FISH results. Thus, in case 2 , the consequence of inv(12) was fusion of exon 3 of $H M G A 2$ with a sequence in intron 1 of the CRADD gene located in $12 \mathrm{q} 22$. The HMGA2$C R A D D$ fusion transcript would code for a putative protein containing amino acid residues 1-83 of HMGA2 (accession number NP_003474.1) corresponding to exons $1-3$ of the gene and $1 \overline{0}$ amino acid residues encoded by $C R A D D$ (ELPAVAVVEY). This pattern is similar to the rearrangements of $H M G A 2$ found in other benign connective tissue tumors, i.e., disruption of the $H M G A 2$ locus leaves intact exons 1-3 which encode the AT-hook domains and separates them from the 3 '-terminal part of the gene $[11,12]$. In uterine leiomyomas, HMGA2 fusion transcripts were reported with various sequences including COX6C (8q22.2), ALDH2 (12q24.12), CCNB1IP1 (14q11.2), RAD51B (14q24.1), and RTVL-H 3_LTR (21q21.2) [13]. However, the 12q14 15 rearrangements, including $\mathrm{t}(12 ; 14)(\mathrm{q} 15 ; \mathrm{q} 23 \sim 24)$, were found to map predominantly to the $5^{\prime}$-region of $H M G A 2$ [14, 15]. The pattern of rearrangements suggests that the primary effect is dysregulated expression of $H M G A 2$, most often

chr8 (q12.1) \begin{tabular}{|l|l|l|l|l|l|l|}
\hline $23.18 \mathrm{p} 22$ & $8 \mathrm{p} 12$ \\
\hline
\end{tabular}

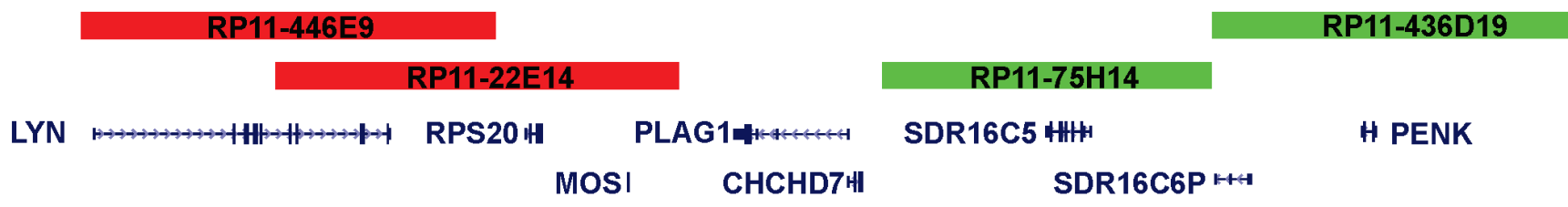

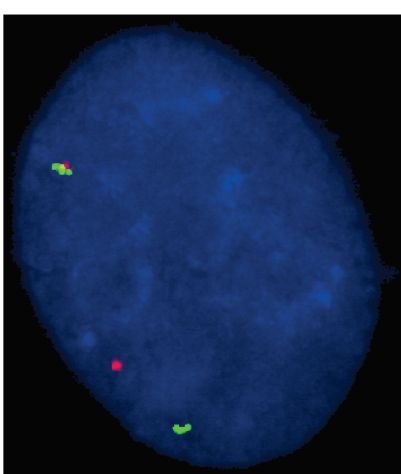

Case 4

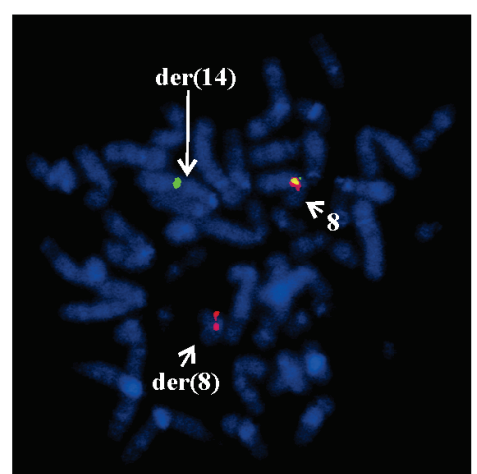

Case 5

Figure 4: Interphase and metaphase FISH analyses of leiomyomas of deep soft tissue from group $\mathbf{2}$ with $8 \mathrm{q}$ anomalies. Ideogram of chromosome 8 with the location of PLAG1 (red box) and the BACs used for FISH experiments are shown. The proximal probe (centromeric, red signal) consisted of the clones RP11-446E9 and RP11-22E14. The distal probe (telomeric, green signal) consisted of the clones RP11-75H14 and RP11-436D19. In case 4, FISH on interphase nuclei showed split between the proximal and distal probes. In case 5 , FISH on metaphase spread showed that the green signal (distal probe) was moved to der(14) whereas the red signal (proximal probe) remained on $\operatorname{der}(8)$. 
by translocation of a chromosome 14 sequence upstream of the 5 -end of HMGA2 [14, 15]. The chromosome aberration either separates from the exons a regulatory element that ordinarily negatively regulates $H M G A 2$ expression, or places a foreign regulatory element near $H M G A 2$ thus overcoming the silencing of this gene observed in normal adult tissues. Such regulatory elements might include an enhancer of gene expression. The paradigm for this mechanism is the overexpression of the MYC gene (8q24) as a result of the reciprocal translocations between chromosome 8 and chromosomes 2,14 , and 22 that harbor immunoglobulin loci expressed in B-lineage lymphatic cells [8].

In cases 1 and 3 (Table 1), which were subjected to RNA-sequencing, fusion transcripts of RPSAP52, the ribosomal protein SA pseudogene 52, were found (Reference Sequence: NR_026825.2, https://www.ncbi. nlm.nih.gov/gene/204010). RPSAP52 has two exons: Exon 1 is located within intron 1 of $H M G A 2$ whereas exon 2 is located $65 \mathrm{kbp}$ upstream of exon 1 of HMGA2. In case 1, exon 1 of RPSAP52 was fused with the noncoding RNA with accession number XR 944195 from chromosome band $14 \mathrm{q} 32.2$. RPSAP52 was the 5 '-end partner in the fusion transcript. In case 3, exon 2 of RPSAP52 was fused with ZFP36L1 which maps on 14q24.1. RPSAP52 was the 3 '-end partner in the ZFP36L1-RPSAP52 fusion transcript. The findings indicate that the breakpoints lie upstream of the 5 '-end of HMGA2 and that, in leiomyomas of deep soft tissue with rearrangements of $12 \mathrm{q} 13 \sim 15$, fusion of $H M G A 2$ is not the only molecular mechanism whereby abnormal expression of this gene can be achieved. Thus, the differences in relative normalized expression of $H M G A 2$ seen in Table 1 could reflect differences in molecular mechanisms behind the abnormal expression of $H M G A 2$ : In case 2, the expression was the result of an $H M G A 2-C R A D D$ fusion transcript that disrupted HMGA2 but left intact exons 1-3 coding for the AT-hook domains and separated them from the $3^{\prime}$-untranslated region of the gene (3'-UTR) [11]. The $3^{\prime}$-UTR of HMGA2 was shown to regulate the transcription of the $H M G A 2$ gene $[16,17]$. In cases 1 and $3, H M G A 2$ expression probably was the result of chromosome 14 sequences being moved upstream of $H M G A 2$ by the chromosome rearrangements. Thus, different regulatory elements could be placed near $H M G A 2$. In the leiomyomas of deep soft tissue without 12q13 15 rearrangements, $H M G A 2$ expression was zero (cases 4 and 6 with 8q rearrangements) or very low (cases 7 and 8). Although the number of leiomyomas of deep soft tissue so far studied is still very low, the findings with regard to 12q13 15 aberrations/expression of HMGA2 seem to be similar to those made in uterine leiomyomas $[14,15]$.

Three out of eight tumors had aberrations of chromosome bands 8q12 13 (cases 4-6; Table 1). FISH examination showed that PLAG1 was split in cases 4 and 5. Moreover, expression analysis of cases 4 and 6 showed that PLAG1 was expressed whereas expression of HMGA2 was absent. Taking the FISH and expression analyses together, PLAG1 seems to be targeted by $8 \mathrm{q}$ aberrations in leiomyomas of deep soft tissue. The difference in PLAG1 expression between cases 4 and 6 could be the result of different regulatory elements being placed near PLAG1 by the different aberrations. Chromosome rearrangements of 8q11 13 but without concomitant

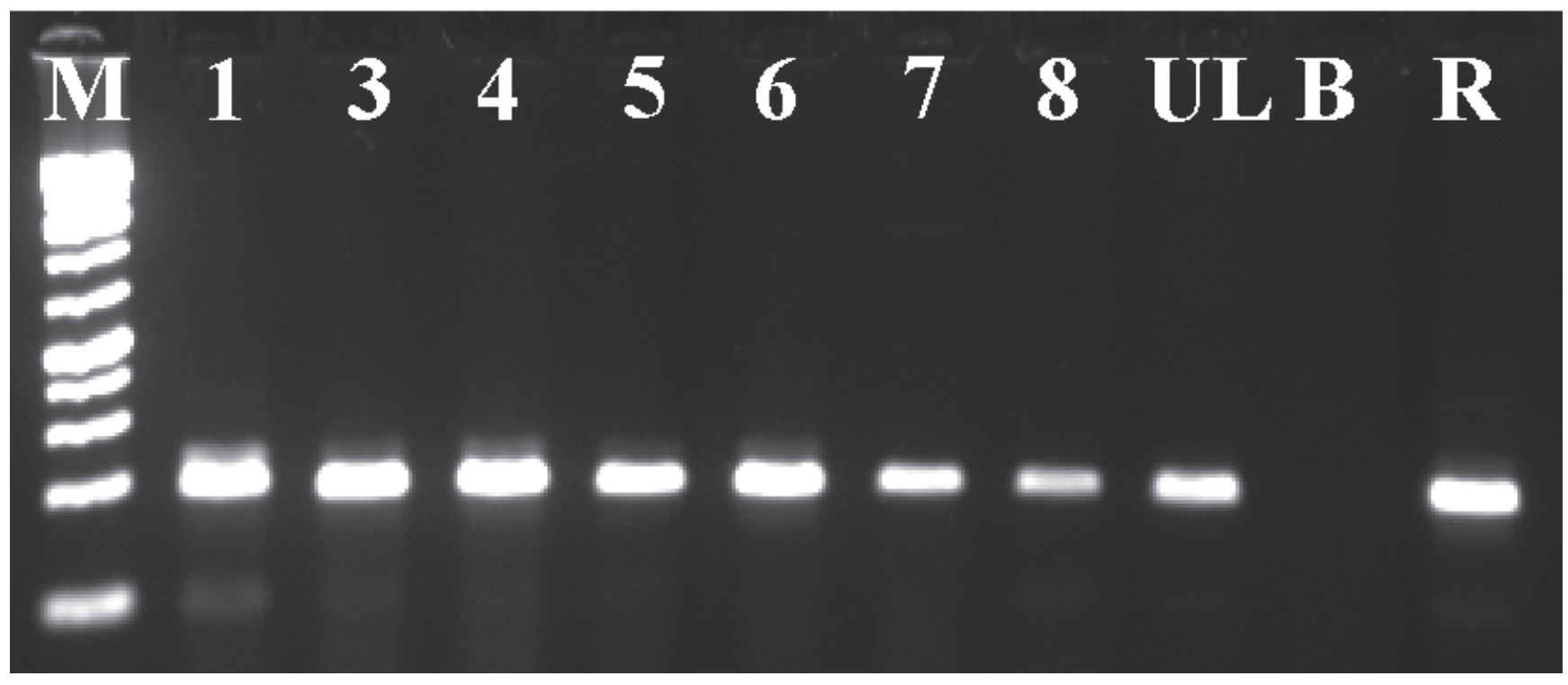

Figure 5: Expression of $M E D 12$ in leiomyomas of deep soft tissue. Gel electrophoresis of the RT-PCR amplified products. The primers MED12-Ex1-F/MED12-Ex3-R amplified a $163 \mathrm{bp}$ cDNA fragment which contained part of exon 1, the entire exon 2, and part of exon 3 of the MED12 gene. All leiomyomas of deep soft tissue, except case 2, were examined (Lanes 1 and 3-8). M, 1 Kb DNA ladder (GeneRuler, Thermo Fisher Scientific). UL, uterine leiomyoma. B, Blank, water in cDNA synthesis. R, positive control, Human Universal Reference Total RNA (Clontech Laboratories, TaKaRa). 
Case 1 RPSAP52 (12q14.3) $X R_{-} 944195(14 \mathrm{q} 32.2)$

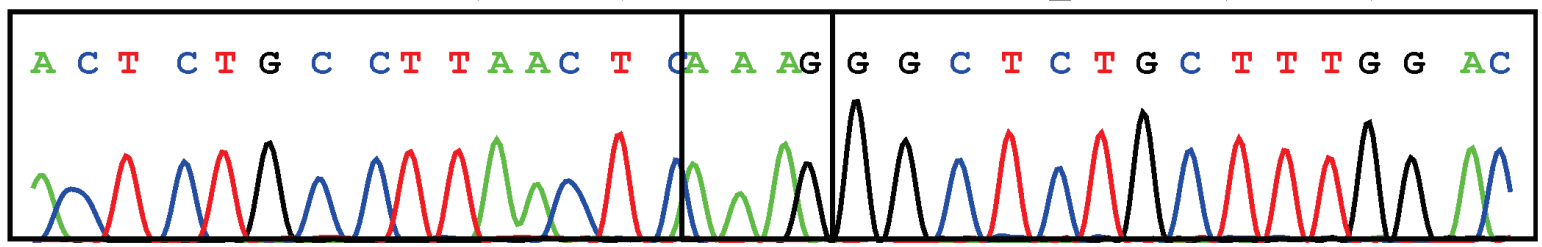

RPSAP 52-4F1

TCCCATTTAGAGAATTCGGGAAGGTTCCCTGCAAGCTTCTGTGGGACCACTAGCACCAGT GGGCACATCGAGAGCAAACACATCGGAGACAAATTTTTCTTTCTTTGTGAACTCTGCCTT AACTCAAAGGGCTCTGCTTTGGACTATAATTTATAAGAAGCCTGGGCTTTGGAGTCAGAC ACATCCAAGTTCAGAGCCCACCTTGATGCTGTGAGATCCTGGCAAAGCCACCCACTCCCT CTGAAAAGTGGATTGCGGAGATTAAGAGAGACTACTGAAGTGCCACGTTTAGGCTGACAT CAGGAGCACCGGTGATACCTCCTTCCCATGTTGCGAAAGCTTTGATTTTGACCCATCCTT GAGTCCTGAAGCTTGAA

nCRNA-411R1

Case $3 \quad$ ZFP36L1 (14q24.1)

RPSAP52 (12q14.3)

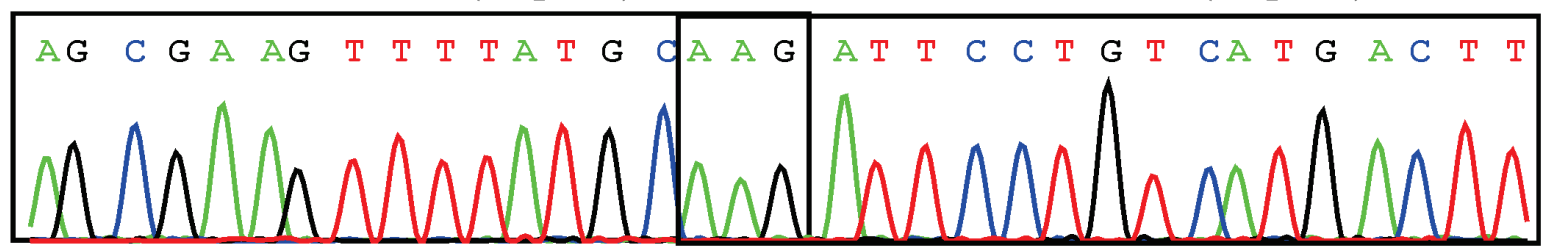

ZFP36L1-876F1

ACTGGCGTGTGGGACTCCAGACAGGAGAGGCTGCGCCTTCCCCGCACCGGGACCTTCGCG ACACACCAGATCCTCGCCCCTGGCTCGCGCGAACGCACAGGATGACCACCACCCTCGTGT CTGCCACCATCTTCGACTTGAGCGAAGTTTTATGCAAGATTCCTGTCATGACTTAAAGAG AAACTTTCACAATGTCTGGAGCCCTTGATGTCCTGCAAATGAAGGAGGAGGATGTCCTTA AGCTCCTTGCAGTGGGAATCCAATTAGGTGGCACCAAATTGACTTCCAAATGGAACAGTA CATCTATAAAAGGAAAGTGATGGCATCTACAGCATAAATCTGAAGAGGACCTGGGAGAAG СTTCTGCTGGCAGGTCA

RPSAP52-329R1

\section{Case 2 HMGA2 (12q14.3)}

$C R A D D(12 \mathrm{q} 22)$

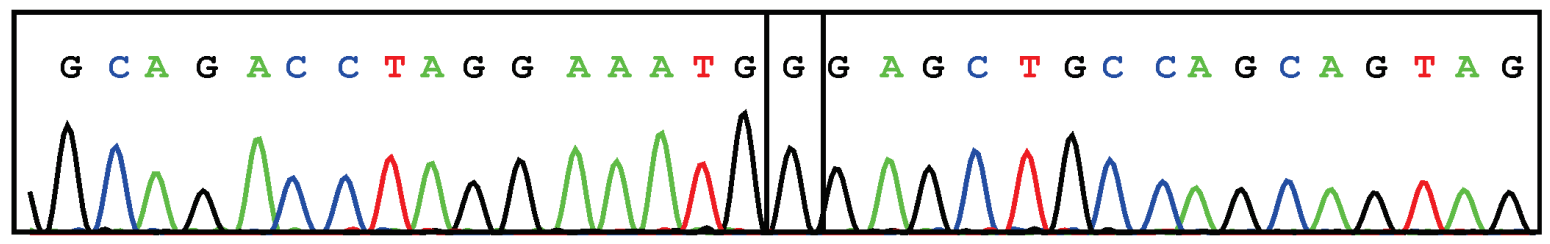

HMGA2-921F1

CCCCAGCGCCTCAGAAGAGAGGACGCGGCCGCCCCAGGAAGCAGCAGCAAGAACCAACCG GTGAGCCCTCTCCTAAGAGACCCAGGGGAAGACCCAAAGGCAGCAAAAACAAGAGTCCCT CTAAAGCAGCTCAAAAGAAAGCAGAAGCCACTGGAGAAAAACGGCCAAGAGGCAGACCTA GGAAATGGGAGCTGCCAGCAGTAGCTGTGGTTGAATACTGAAGGGGAAAAGAAGCTACAA AGGAAGCCCCAGTGGAGCATCTTTGACTTCTAACCCATAGGCCAGGGGATCGGGAAGACG CATACCAGTGAGTGACTCATAGGTCACACATACCAGTGGGTGACTCAAGCCACTACCCTT TGGA

CRADD-Intr-R1

Figure 6: RT-PCR results on fusion genes related to $12 q / H M G A 2$ in cases 1,3 , and 2 . The amplified cDNA fragments were direct sequenced. The partial chromatograms, which are shown, contain the fusion points. The chromosome locations of the fusion partners are shown in parentheses. The amplified cDNA sequences are also shown. Primers are in red. Common nucleotides found at the fusion points are shown in green boxes. 
involvement of 12q13 15 (where HMGA2 maps) or $6 \mathrm{p} 21$ (where the HMGA1 gene is situated) was reported in six uterine leiomyomas, one leiomyoma of the vagina, and one intraabdominal leiomyoma [9]. However, in the leiomyoma of the vulva with karyotype $46, \mathrm{XX}, \mathrm{t}(7 ; 8)$ (p13;q11.2), the PLAG1 gene was not altered by the translocation [18].

Recently, uterine leiomyomas with HMGA2 aberrations were shown to display highly significant up-regulation of PLAG1 [19, 20]. Both the leiomyomas with 12q14 15 rearrangements/expression of HMGA2 (cases 1-3; Table 1) and case 7 with del(7)(q22) expressed PLAG1 (Table 1). No expression of PLAG1 was seen in case 8 which had neither 12q13 15 change nor del(7) (q22) (Table 1).

The terminal deletion $\operatorname{del}(7)(q 22)$ found in case 7 (Table 1) was also reported in uterine leiomyomas [9]. However, an interstitial deletion of chromosome 7, del(7) (q22q32), is much more frequent as it occurs in $20 \%$ of karyotypically abnormal uterine leiomyomas $[8,9]$. The pathogenetically important region in $7 \mathrm{q} 22$ was in one study narrowed down to a $500 \mathrm{~kb}$ gene-dense area [21]. Furthermore, in two uterine leiomyomas, one with a pericentric and the other with a paracentric inversion of chromosome 7, the inversions targeted the cut-like homeobox 1 (CUX1) gene on chromosomal band 7q22.1 [22]. Whether this represents the whole pathogenetic story behind 7q-deletions in leiomyomas, remains a moot point.

In case 8 , rearrangements of chromosome bands $3 q 21 \sim 23$ and 11q21 22 were found. Involvement of these bands was previously reported also in uterine leiomyomas. Deletion of 3q21 was reported as the sole anomaly in a uterine leiomyoma [23], and Dal Cin et al [24] reported an interstitial deletion of the long arm of chromosome 3 as the sole abnormality in another three such tumors. Although there was cytogenetic heterogeneity of the deleted 3q segment (q13.3-q27 in case 1, q12-q24 in case 2 , and q21-q27 in case 3), the authors concluded that the involvement of $3 q$ was significant enough to define a new cytogenetic subgroup [24]. Indeed, a more recent study described two more uterine leiomyomas with deletions of the long arm of chromosome 3 [25]. Both led to loss of the $M E D 12 L$ gene ( $3 \mathrm{q} 25.1)$ which shows strong similarity with MED12. Finally, the translocations $\mathrm{t}(5 ; 11)(\mathrm{q} 13 ; \mathrm{q} 21)$ and $\mathrm{t}(6 ; 11)(\mathrm{p} 23 ; \mathrm{q} 21)$ were reported in two uterine leiomyomas as the sole cytogenetic abnormality [26, 27]. The molecular consequences behind rearrangements of $3 \mathrm{q} 21$ and 11q21 remain unknown.

A number of recent studies have reported mutations in exon 2 of the MED12 gene in most uterine leiomyomas [28]. Mutations of MED12 were found in leiomyomas with a normal karyotype, with deletions or rearrangements of the long arm of chromosome 7 as sole anomaly, and with $6 \mathrm{p} 21 \sim 23$ abnormalities leading to HMGA1 rearrangement/overexpression, and it was concluded that they precede the chromosomal aberrations [29]. On the other hand, mutations of MED12 have not been detected in uterine leiomyomas with $12 \mathrm{q} 14 \sim 15$ rearrangements resulting in overexpression of $H M G A 2$ [29, 30]. In a recent study, MED12 mutations were also found in 10 out of $29(34 \%)$ cases of leiomyoma/leiomyomatosis in pelvic/retroperitoneal sites [5]. In another study, Ravegnini et al [31] found MED12 mutations in 3 of 19 $(16 \%)$ extrauterine leiomyomas (one each from the ovary, kidney, and retroperitoneum). In contrast, none of the 42 extrauterine leiomyomas had MED12 mutations in exon 2 in the study published by Matsubara et al [32]. In the present study, no mutations in exon 2 of MED12 were found in eight leiomyomas of deep soft tissue. Thus, the role of exon 2 MED12 mutations in the development of extrauterine leiomyomas, including leiomyomas of deep soft tissue, appears to be limited.

In a previous study [6], we reported the finding of a KAT6B-KANSL1 fusion gene in a retroperitoneal leiomyoma with $\mathrm{t}(10 ; 17)(\mathrm{q} 22 ; \mathrm{q} 21)$. Uterine leiomyomas with $\mathrm{t}(10 ; 17)$ and disruption of the $K A T 6 B$ gene were also described [33]. In another study [7], we found an EWSR1$P B X 3$ fusion gene in a retroperitoneal leiomyoma carrying a $\mathrm{t}(9 ; 22)(\mathrm{q} 33 ; \mathrm{q} 12)$ chromosome translocation. The present findings together with data on those two previously described tumors show that leiomyomas of deep soft tissue are genetically heterogeneous but with marked similarities to uterine leiomyomas.

\section{MATERIALS AND METHODS}

\section{Patients}

The material consisted of eight samples from tumors diagnosed as leiomyoma of deep soft tissue (Table 1), all surgically removed at The Norwegian Radium Hospital between 2006 and 2015. The study was approved by the Regional Committee for Medical and Health Research Ethics, South-East Norway (REK Sør-Øst; http:// helseforskning.etikkom.no). Written informed consent was obtained from the patients. The consent included acceptance that the clinical details be published. The ethics committee's approval included a review of the consent procedure. All patient information has been de-identified.

\section{Chromosome banding analysis and FISH}

Samples from the surgically removed tumors were received and analyzed cytogenetically as part of our diagnostic routine using standard techniques [34]. Chromosome preparations were G-banded using Wright's stain (Sigma-Aldrich; St Louis, MO, USA). The subsequent cytogenetic analysis and karyotype description followed The International System for Human Cytogenetic Nomenclature (ISCN) 2016 guidelines [35]. 
FISH analysis based on the karyotypic findings (see below) was performed on both interphase nuclei and metaphase plates. HMGA2 BAC clones were retrieved from the Human genome high-resolution BAC rearrayed clone set (the "32k set"; BACPAC Resources, http://bacpac.chori.org/pHumanMinSet.htm). Detailed information on the $H M G A 2$ BAC clones is given elsewhere [36]. A homemade breakapart $H M G A 2$ probe was used. The $5^{\prime}$-end of the probe (red signal) was constructed from a pool of the clones RP11-185K16, RP11-30I11, and RP11-662G15. The 3'-end of the probe (green signal) was constructed from a pool of the clones RP118B13, RP11-745O10, and RP11-263A04. All of them map to chromosome subband $12 \mathrm{q} 14.3$ and cover the HMGA2 locus [36].

For the PLAG1 locus, clones were based on the contigs used to construct the GRCh38 (hg38) genome assembly as well as the NCBI clone end mappings from the NCBI Clone DBdatabase (http://www.ncbi.nlm.nih. gov/clone/library/genomic/12/). A homemade breakapart PLAG1 probe was used. The proximal or centromeric probe (red signal) consisted of the clones RP11-446E9 (accession number AC046176, position chr8:5587028856054628) and RP11-22E14 (accession number AC083961, position chr8:55956731-56135453). The distal or telomeric probe (green signal) consisted of the clones RP11-75H14 (accession number AC103849, position chr8:56227167-56374265) and RP11-436D19 (accession number AC023464, position chr8: 56299162-56459550).

DNA was extracted, the probes were labelled with Fluorescein-12-dCTP (PerkinElmer, Boston, MA, USA) and Texas Red-5-dCTP (PerkinElmer) in order to obtain green and red signals, respectively, using the Abbott's nick translation kit (Des Plaines, IL, USA), and hybridized according to Abbott Molecular recommendations (http:// www.abbottmolecular.com/home.html). Chromosome preparations were counterstained with $0.2 \mu \mathrm{g} / \mathrm{ml}$ DAPI and overlaid with a $24 \times 50 \mathrm{~mm}^{2}$ coverslip. Fluorescent signals were captured and analyzed using the CytoVision system (Leica Biosystems, Newcastle, UK).

\section{RNA extraction and cDNA synthesis}

Total RNA was extracted using miRNeasy Mini Kit according to the manufacturer's instructions (Qiagen Nordic, Oslo, Norway) from frozen and stored at -80 ${ }^{\circ} \mathrm{C}$ tumor tissue adjacent to that used for cytogenetic analysis and histologic examination. No material for RNA extraction was available from case 5. The tissue was disrupted and homogenized in Qiazol Lysis Reagent (Qiagen) using $5 \mathrm{~mm}$ stainless steel beads and TissueLyser II (Qiagen). Subsequently, total RNA was purified using QIAcube (Qiagen). The RNA quality was evaluated using the Experion Automated Electrophoresis System (Bio-Rad Laboratories, Oslo, Norway).

One $\mu \mathrm{g}$ of total RNA was reverse-transcribed in a $20 \mu \mathrm{L}$ reaction volume using iScript Advanced cDNA Synthesis Kit for RT-qPCR according to the manufacturer's instructions (Bio-Rad Laboratories, Oslo, Norway). The cDNA was diluted to $50 \mu \mathrm{l}$ of which $1 \mu \mathrm{l}$ was used as template in subsequent PCR assays.

\section{Expression analysis of $H M G A 2$ and $P L A G 1$}

Real time PCR was carried out to determine the expression level of the HMGA2 and PLAG1 genes using TaqMan gene expression assays (Applied Biosystems, Foster City, CA, USA) Hs04397751_m1 (HMGA2 exons 2-3 in sequence with accession number NM_00003483) and Hs00965049_g1 (PLAG1 exons 4-5 in sequence with accession number NM_002655.2). The genes $A C T A 2, D E S$, and CALD1 which code for aortic smooth muscle actin, desmin, and caldesmon 1, respectively, were used as endogenous controls for relative gene expression quantification. The assay for ACTA2 was the Hs00426835_g1 which spans the boundary between exons 2 and 3 (accession number NM 001613.2). The assay for $D E S$ was the Hs00157258_m1 which spans the boundary between exons 6 and 7 (accession number NM_001927.3). The assay for CALD1 was the Hs00921982_ml which spans the boundary between exons 12 and 13 (accession number NM_004342.6).

Human Universal Reference Total RNA was used as control (Clontech Laboratories, TaKaRa Bio Group, France). According to the company's information, it is a mixture of total RNAs from a collection of adult human tissues chosen to represent a broad range of expressed genes. Both male and female donors are represented.

Four replicates of each sample and endogenous control were used. The $20 \mu \mathrm{L}$ reaction volume contained 1x TaqMan Universal Mix, 1x 20x TaqMan Gene Expression Mix, and $2 \mu \mathrm{L}$ cDNA (40 ng equivalent of RNA). Real time PCR was run on a CFX96 Touch ${ }^{\mathrm{TM}}$ Real-Time PCR Detection System (Bio-Rad Laboratories). The thermal cycling included an initial step at $50{ }^{\circ} \mathrm{C}$ for $2 \mathrm{~min}$, followed by $10 \mathrm{~min}$ at $95^{\circ} \mathrm{C}$ and 40 cycles of 15 sec at $95{ }^{\circ} \mathrm{C}$, and $1 \mathrm{~min}$ at $60^{\circ} \mathrm{C}$. The data were analyzed using the Bio-Rad CFX Manager 3.1 Software (Bio-Rad Laboratories). The $2^{-\Delta \Delta \mathrm{Cq}}$ (Livak) method for relative gene expression was used [37]. Expression of the different transcripts was normalized to ACTA2, DES, and CALD1 expression before the relative expression was calculated and set as 1 for human reference (Table 1).

\section{RT-PCR analysis of the MED12 gene}

The primers MED12-Ex1-F (5'-TTA CCC TCA GGA CCC CAA ACA G-3') and MED12-Ex3-R (5'-TGC AAT AAT GCT GCT GAA GTT GG-3') were used for assessment of the expression of MED12 and detection of possible mutations in exon 2 of MED12. Detailed 
information about the assay is given elsewhere [6]. A uterine leiomyoma with $\mathrm{t}(12 ; 14)(\mathrm{q} 14 \sim 15 ; \mathrm{q} 23 \sim 24)$ and the Human Universal Reference Total RNA were used as controls.

\section{$3^{\prime}$ - Rapid amplification of cDNA ends (3'- RACE)}

The 3'-RACE methodology used was described in detail elsewhere [36].

\section{RNA-sequencing}

Three $\mu \mathrm{g}$ of total RNA were sent for high-throughput paired-end RNA-sequencing at the Norwegian Sequencing Centre, Ulleval Hospital (http://www.sequencing.uio.no/). Detailed information about the RNA sequencing is given elsewhere [6, 38]. The softwares deFuse, FusionCatcher, and TopHat-Fusion were used for the discovery of fusion transcripts [39-41].

\section{RT-PCR analyses for verification of fusion transcripts}

For reverse transcriptase-Polymerase Chain Reaction (RT-PCR), the $25 \mu \mathrm{L}$ PCR volume contained $12.5 \mu$ L Premix Ex Taq ${ }^{\mathrm{TM}}$ DNA Polymerase Hot Start Version Taq (Takara Bio Europe/SAS, Saint-Germain-enLaye, France), cDNA, and $0.4 \mu \mathrm{M}$ of each of the forward and reverse primers. The PCR was run on a C-1000 Thermal cycler (Bio-Rad Laboratories) with an initial denaturation at $94{ }^{\circ} \mathrm{C}$ for $30 \mathrm{sec}$, followed by 35 cycles of $7 \mathrm{sec}$ at $98{ }^{\circ} \mathrm{C}, 30 \mathrm{sec}$ at $60{ }^{\circ} \mathrm{C}, 1 \mathrm{~min}$ at $72{ }^{\circ} \mathrm{C}$, and a final extension for $5 \mathrm{~min}$ at $72{ }^{\circ} \mathrm{C}$. The primer combinations were the following: In case 1, RPSAP52-4F1 (TCCCATTTAGAGAATTCGGGAAGGT) and ncRNA411R1 (TTCAAGCTTCAGGACTCAAGGATGG); in case 2, HMGA2-921F1 (CCCCAGCGCCTCAGAAGAGA) and CRADDIntr-R1 (TCCAAAGGGTAGTGGCTTGAGTCA); and in case 3, ZFP36L1-876F1 (ACTGGCGTGTGGGACTCCAGAC) and RPSAP52329R1 (TGACCTGCCAGCAGAAGCTTCTC). Three $\mu \mathrm{L}$ of the PCR products were stained with GelRed (Biotium, Hayward, CA, USA), analyzed by electrophoresis through $1.0 \%$ agarose gel, and photographed. The remaining PCR products were purified using the Qiaquick PCR purification kit (Qiagen) or the QIAquick Gel Extraction Kit (Qiagen, Hilden, Germany) and direct sequenced using the dideoxy procedure with the ABI Prism BigDye terminator v1.1 cycle sequencing kit (ThermoFisher Scientific, Waltman, MA, USA) on the Applied Biosystems Model 3500 Genetic Analyzer sequencing system. BLAST and BLAT softwares (http://www.ncbi. nlm.nih.gov/BLAST/, http://genome.ucsc.edu/cgi-bin/
hgBlat?command=start) were used for computer analysis of sequence data.

\section{Authors' contributions}

Ioannis Panagopoulos designed the research, evaluated the cytogenetic data, did experiments, and wrote the manuscript. Ludmila Gorunova produced and evaluated the cytogenetic data. Marta Brunetti and Antonio Agostini performed molecular genetic experiments. Hege Kilen Andersen performed the FISH experiments. Ingvild Lobmeier and Bodil Bjerkehagen performed and evaluated the pathologic examinations. Sverre Heim supervised the project, evaluated the cytogenetics, and wrote the manuscript. All authors read and approved the final version of the manuscript.

\section{CONFLICTS OF INTEREST}

The authors have no conflicts of interest to disclose.

\section{FUNDING}

This study was supported by grants from the Norwegian Radium Hospital Foundation.

\section{Editorial note}

This paper has been accepted based in part on peerreview conducted by another journal and the authors' response and revisions as well as expedited peer-review in Oncotarget.

\section{REFERENCES}

1. Miettinen MM, Quade B. Leiomyoma of deep soft tissue. In: Fletcher CDM, Bridge JA, Hogendoorn PCW and Mertens F, eds. WHO Classification of Tumours of Soft Tissue and Bone. Lyon, France: International Agency for Research on Cancer; 2013; pp. 110-111.

2. Billings SD, Folpe AL, Weiss SW. Do leiomyomas of deep soft tissue exist? An analysis of highly differentiated smooth muscle tumors of deep soft tissue supporting two distinct subtypes. Am J Surg Pathol. 2001; 25:1134-1142.

3. Paal E, Miettinen M. Retroperitoneal leiomyomas: a clinicopathologic and immunohistochemical study of 56 cases with a comparison to retroperitoneal leiomyosarcomas. Am J Surg Pathol. 2001; 25:1355-1363.

4. Poliquin V, Victory R, Vilos GA. Epidemiology, presentation, and management of retroperitoneal leiomyomata: systematic literature review and case report. J Minim Invasive Gynecol. 2008; 15:152-160.

5. Schwetye KE, Pfeifer JD, Duncavage EJ. MED12 exon 2 mutations in uterine and extrauterine smooth muscle 
tumors. Hum Pathol. 2014; 45:65-70.

6. Panagopoulos I, Gorunova L, Bjerkehagen B, Heim S. Novel KAT6B-KANSL1 Fusion Gene Identified by RNA Sequencing in Retroperitoneal Leiomyoma with $\mathrm{t}(10 ; 17)$ (q22;q21). PLoS One. 2015; 10:e0117010.

7. Panagopoulos I, Gorunova L, Bjerkehagen B, Heim S. Fusion of the genes EWSR1 and PBX3 in retroperitoneal leiomyoma with $\mathrm{t}(9 ; 22)(\mathrm{q} 33 ; \mathrm{q} 12)$. PLoS One. 2015; 10:e0124288.

8. Heim S, Mitelman F, Editors. Cancer Cytogenetics: Chromosomal and Molecular Genetic Aberrations of Tumor Cells, 4th Edition. Chichester, UK: Wiley-Blackwell; 2015. pp 648.

9. Mitelman F, Johansson B, Mertens F, Editors. Mitelman Database of Chromosome Aberrations and Gene Fusions in Cancer (2017). http://cgap.nci.nih.gov/Chromosomes/ Mitelman.

10. Guardiola MT, Dobin SM, Dal Cin P, Donner LR. Pericentric inversion (12)(p12q13-14) as the sole chromosomal abnormality in a leiomyoma of the vulva. Cancer Genet Cytogenet. 2010; 199:21-23.

11. Cleynen I, Van de Ven WJ. The HMGA proteins: a myriad of functions (Review). Int J Oncol. 2008; 32:289-305.

12. Fedele M, Fusco A. HMGA and cancer. Biochim Biophys Acta. 2010; 1799:48-54.

13. Commandeur AE, Styer AK, Teixeira JM. Epidemiological and genetic clues for molecular mechanisms involved in uterine leiomyoma development and growth. Hum Reprod Update. 2015; 21:593-615.

14. Quade BJ, Weremowicz S, Neskey DM, Vanni R, Ladd C, Dal Cin P, Morton CC. Fusion transcripts involving HMGA2 are not a common molecular mechanism in uterine leiomyomata with rearrangements in $12 \mathrm{q} 15$. Cancer Res. 2003; 63:1351-1358.

15. Schoenberg Fejzo M, Ashar HR, Krauter KS, Powell WL, Rein MS, Weremowicz S, Yoon SJ, Kucherlapati RS, Chada K, Morton CC. Translocation breakpoints upstream of the HMGIC gene in uterine leiomyomata suggest dysregulation of this gene by a mechanism different from that in lipomas. Genes Chromosomes Cancer. 1996; 17:1-6.

16. Borrmann L, Wilkening S, Bullerdiek J. The expression of HMGA genes is regulated by their 3'UTR. Oncogene. $2001 ; 20: 4537-4541$

17. Kristjansdottir K, Fogarty EA, Grimson A. Systematic analysis of the Hmga2 3' UTR identifies many independent regulatory sequences and a novel interaction between distal sites. RNA. 2015; 21:1346-1360.

18. Horton E, Dobin SM, Debiec-Rychter M, Donner LR. A clonal translocation $(7 ; 8)(\mathrm{p} 13 ; \mathrm{q} 11.2)$ in a leiomyoma of the vulva. Cancer Genet Cytogenet. 2006; 170:58-60.

19. Klemke M, Muller MH, Wosniok W, Markowski DN, Nimzyk R, Helmke BM, Bullerdiek J. Correlated expression of HMGA2 and PLAG1 in thyroid tumors, uterine leiomyomas and experimental models. PLoS One.
2014; 9:e88126.

20. Mehine M, Kaasinen E, Heinonen HR, Makinen N, Kampjarvi K, Sarvilinna N, Aavikko M, Vaharautio A, Pasanen A, Butzow R, Heikinheimo O, Sjoberg J, Pitkanen $\mathrm{E}$, et al. Integrated data analysis reveals uterine leiomyoma subtypes with distinct driver pathways and biomarkers. Proc Natl Acad Sci U S A. 2016; 113:1315-1320.

21. Sell SM, Tullis C, Stracner D, Song CY, Gewin J. Minimal interval defined on 7q in uterine leiomyoma. Cancer Genet Cytogenet. 2005; 157:67-69.

22. Schoenmakers EF, Bunt J, Hermers L, Schepens M, Merkx G, Janssen B, Kersten M, Huys E, Pauwels P, DebiecRychter M, van Kessel AG. Identification of CUX1 as the recurrent chromosomal band 7q22 target gene in human uterine leiomyoma. Genes Chromosomes Cancer. 2013; 52:11-23.

23. Mark J, Havel G, Grepp C, Dahlenfors R, Wedell B. Chromosomal patterns in human benign uterine leiomyomas. Cancer Genet Cytogenet. 1990; 44:1-13.

24. Dal Cin P, Moerman P, Deprest J, Brosens I, Van den Berghe H. A new cytogenetic subgroup in uterine leiomyoma is characterized by a deletion of the long arm of chromosome 3. Genes Chromosomes Cancer. 1995; 13:219220.

25. Holzmann C, Markowski DN, Bartnitzke S, Koczan D, Helmke BM, Bullerdiek J. A rare coincidence of different types of driver mutations among uterine leiomyomas (UL). Mol Cytogenet. 2015; 8:76.

26. Nezhad MH, Drieschner N, Helms S, Meyer A, Tadayyon M, Klemke M, Belge G, Bartnitzke S, Burchardt K, Frantzen C, Schmidt EH, Bullerdiek J. 6p21 rearrangements in uterine leiomyomas targeting HMGA1. Cancer Genet Cytogenet. 2010; 203:247-252.

27. Stern C, Deichert U, Thode B, Bartnitzke S, Bullerdiek J. [Cytogenetic subtyping of 139 uterine leiomyoma]. [Article in German]. Geburtshilfe Frauenheilkd. 1992; 52:767-772.

28. Mehine M, Makinen N, Heinonen HR, Aaltonen LA, Vahteristo P. Genomics of uterine leiomyomas: insights from high-throughput sequencing. Fertil Steril. 2014; 102:621-629.

29. Markowski DN, Bartnitzke S, Loning T, Drieschner N, Helmke BM, Bullerdiek J. MED12 mutations in uterine fibroids--their relationship to cytogenetic subgroups. Int $\mathrm{J}$ Cancer. 2012; 131:1528-1536.

30. Bertsch E, Qiang W, Zhang Q, Espona-Fiedler M, Druschitz S, Liu Y, Mittal K, Kong B, Kurita T, Wei JJ. MED12 and HMGA2 mutations: two independent genetic events in uterine leiomyoma and leiomyosarcoma. Mod Pathol. 2014; 27:1144-1153.

31. Ravegnini G, Marino-Enriquez A, Slater J, Eilers G, Wang Y, Zhu M, Nucci MR, George S, Angelini S, Raut CP, Fletcher JA. MED12 mutations in leiomyosarcoma and extrauterine leiomyoma. Mod Pathol. 2013; 26:743-749.

32. Matsubara A, Sekine S, Yoshida M, Yoshida A, Taniguchi 
H, Kushima R, Tsuda H, Kanai Y. Prevalence of MED12 mutations in uterine and extrauterine smooth muscle tumours. Histopathology. 2013; 62:657-661.

33. Moore SD, Herrick SR, Ince TA, Kleinman MS, Dal Cin P, Morton CC, Quade BJ. Uterine leiomyomata with t(10;17) disrupt the histone acetyltransferase MORF. Cancer Res. 2004; 64:5570-5577.

34. Mandahl N. Methods in solid tumour cytogenetics. In: Rooney DE, Editor. Human cytogenetics: malignancy and acquired abnormalities. New York: Oxford University Press; 2001. pp. 165-203.

35. McGowan-Jordan J, Simons A, Schmid M. ISCN 2016: An International System for Human Cytogenetic Nomenclature. Basel: Karger; 2016.

36. Panagopoulos I, Bjerkehagen B, Gorunova L, Taksdal I, Heim S. Rearrangement of chromosome bands 12q14 15 causing HMGA2-SOX5 gene fusion and HMGA2 expression in extraskeletal osteochondroma. Oncol Rep. 2015; 34:577-584.

37. Livak KJ, Schmittgen TD. Analysis of relative gene expression data using real-time quantitative PCR and the 2(-Delta Delta C(T)) Method. Methods. 2001; 25:402-408.

38. Panagopoulos I, Gorunova L, Bjerkehagen B, Heim S. The "Grep" Command But Not FusionMap, FusionFinder or ChimeraScan Captures the CIC-DUX4 Fusion Gene from Whole Transcriptome Sequencing Data on a Small Round Cell Tumor with $\mathrm{t}(4 ; 19)(\mathrm{q} 35 ; \mathrm{q} 13)$. PLoS One. 2014; 9:e99439.

39. Kim D, Salzberg SL. TopHat-Fusion: an algorithm for discovery of novel fusion transcripts. Genome Biol. 2011; 12:R72.

40. McPherson A, Hormozdiari F, Zayed A, Giuliany R, Ha G, Sun MG, Griffith M, Heravi Moussavi A, Senz J, Melnyk N, Pacheco M, Marra MA, Hirst M, et al. deFuse: an algorithm for gene fusion discovery in tumor RNA-Seq data. PLoS Comput Biol. 2011; 7:e1001138.

41. Nicorici D, Satalan H, Edgren H, Kangaspeska S, Murumagi A, Kallioniemi O, Virtanen S, Kikku O. FusionCatcher - a tool for finding somatic fusion genes in paired-end RNAsequencing data. bioRxiv. 2014. 